\title{
EFFECT OF IRRIGATION INTERVALS AND FOLIAR FERTILIZATION ON LEMONGRASS (Cymbopogon citratus (DC.) Stapf) PLANT: \\ A- Effects on yield and essential oil production and constituents Abdel-kader, H.H.; ${ }^{*}$ Seham M. A. El-Gamal;** Ali M. Hamza;* Hekmat, Y. Massoud* and Fatma K. Youssef \\ * Vegt. and Flor. Dept., Fac. of Agric. Mansoura Univ. \\ ${ }^{* *}$ Med. and Arom. Plants, Dept., Hort. Res. Inst., Agric. Res. Center.
}

\begin{abstract}
A field experiment was carried out on Cymbopogen citratus (DC.) Stapf plant during two summer years of 2011 and 2012 at a private Farm located in NewDomiata, Domiate Governorate, to study the effect of three irrigation intervals $(3,6$ and 12 days) and two foliar applications with Super Bluegreen and / or Super Cetrin at (75, 100 and $150 \mathrm{ppm}$ ) on yield and essential oil production and composition of lemongrass.

The physical and chemical properties of the oil were determined and are included in this study. G.L.C. separation of the essential oil revealed 6 identified compounds (myrcene - limonene - linalool - neral (citral b) - geranial (citral a) and genaryl acetate). Generally the main components of lemongrass oil was neral (citral b) and geranial (citral a) which achieved the largest values.

The obtained results showed that:

- Irrigation intervals every 3days increased herb yield/plant and /fed.

- Irrigation intervals every 12 days increased essential oil \% and oil yield per plant and per fed, in addition to the main components (citral) in lemongrass leaves.

- Foliar spraying with Super Cetrin gave the highest values of all characters compared to Super Bluegreen in both years.

- The grass yield and essential oil \% and oil yield/plant and /fed were higher in the first cut $\left(1^{\text {st }}\right.$ July) than to the second cut $\left(1^{\text {st }}\right.$ October $)$ during the two years especially in the second year.

- Herb fresh and dry weights / plant, dry yield / fed as well as essential oil \% and oil yield per plant and per fed and the main components (citral) percentage were significantly increased by the mixture of foliar application (Super Bluegreen + Super Cetrin) at $100 \mathrm{ppm}$ in both years.

Therefore, it could be recommended that irrigation intervals every 12 days and foliar application with the mixture of Super Bluegreen + Super Cetrin at the rate of 100 ppm maximize the lemongrass essential oil yield and citral content.
\end{abstract}

\section{INTRODUCTION}

The cultivated species Cymbopogen citrates, Fam. Poaceae grows in tropical and subtropical regions around the world. Lemongrass is tufted perennial grasses with numerous stiff stems arising from a short, rhizomatous rootstock. The grass prefers well drained soil a pH of 6-7, and the best soil for this plant has a texture that is sandy (Jain et al., 1994). The first cutting of grass is taken about 3 months after planting, thereafter every 6-8 weeks. The fresh grass yield ranges from 3 to 10 tones /cut /ha depending on soil fertility, agro climatic conditions and management. The grass yield is the lowest in the first year and highest in the third or fourth year of planting (Pal et al., 1994). 
It is an important medicinal and aromatic plant that contains high quality essential oil of lemon scent. Lemongrass have diverse uses in pharmaceutical, cosmetics, food and flavor, and agriculture industries (Akhila, 2010). Studies on extracts from lemongrass leaves have demonstrated antioxidant, anti-microbial and anti-fungal activities (Matasyoh et al., 2011). The oil yield is around $100-125 \mathrm{~kg} / \mathrm{ha} /$ year, (Joy et al., 2001).

on the other hand, Mohamed et al. (2012) mentioned that the average of the essential oil recovery is $2.12-2.45 \%$. The main component in the volatile from $C$. citratus shoots was citral-a $(53.98 \%)$, the second was citral-b $(34.40 \%$ ), and the others were under $4 \%$, (Chinese et al., 2005). In addition to citral, the essential oil of Cymbopogon spp. consists of small quantities of geraniol, geranyl acetate and myrcene (Weiss, 1997). Lemon grass herb parts, whether fresh or dried, are also rich source of minerals like potassium, zinc, calcium, iron, manganese, copper, and magnesium. Fresh herb is also containing small amounts of anti-oxidant vitamins such as vitamin-A and $C$.

At present and more so in the future, irrigated agriculture will take place under water scarcity. Insufficient water supply for irrigation will be the norm rather than the exception, and irrigation management will shift from emphasizing production per unit area towards maximizing the production per unit of water consumed (water productivity). To cope with scarce supplies, deficit irrigation, defined as the application of water below full crop-water requirements is an important tool to achieve the goal of reducing irrigation water use (Fereres and Soriano, 2006).

Detpiratmongkol et al. (2005) determined the effects of irrigation frequency (every 3,7 and 15 days) and rates $(20,30$, and $40 \mathrm{~mm}$ of water) on the growth and yield of lemongrass. Depending upon the rainfall and its distribution, the field is to be irrigated at an interval of 3 days during the first month and 7-10 day interval thereafter. After the establishment of plants, irrigation schedule is adjusted depending on water holding capacity of the soil and weather conditions.

Fertilizers are used in order to supplement the natural nutrient supply in the soil, especially to correct the yield - limiting factors. Zinc plays an important role in the composition and characterization of root exudates in Poaceae family grown under stress condition (Reffat and Balbaa 2001). Foliar application of micronutrients mixture $(\mathrm{Zn}, \mathrm{Mn}$, and $\mathrm{Fe})$ significantly increased lemongrass fresh weight and dry mass (Shoala, 1992 and Refaat, 1996).

Maximizing oil production of lemongrass and reducing irrigation water use was the aim of this study by using different irrigation intervals and foliar fertilization treatments.

\section{MATERIALS AND METHODS}

The field experiment was carried out on lemongrass plants during two consequent summer years of 2011 and 2012 at a private Farm, New Domitta, Domitta Governate which soil is sandy. Soil samples were obtained at $30 \mathrm{~cm}$ deep from soil surface and were analyzed at laboratories of Agric. Res. Center, Ministry of Agric. Some physical and chemical properties of soil are presented in Table (1). 
The site was prepared and divided into plots. Each plot was $7.20 \mathrm{~m}^{2}$ with 3 rows, $60 \mathrm{~cm}$ apart. Plants were propagated by plant divisions of healthy plants with extensive roots and were treated with fungicide prior to planting. Planting was done on $21^{\text {st }}$ of March, and plant divisions were planted 10-15 $\mathrm{cm}$ deep, and spaced at $55 \mathrm{~cm}$ apart. Each row contained 5 plants with a total number of 15 plants per plot. Nitrogen in the form of ammonium sulfate $(20.5 \% \mathrm{~N})$ at a rate of $60 \mathrm{~kg} \mathrm{~N} /$ fed., phosohorus in the form of calcium superphosphate $\left(15.5 \% \mathrm{P}_{2} \mathrm{O}_{5}\right)$ at a rate of $30 \mathrm{~kg} \mathrm{P}_{2} \mathrm{O}_{5} /$ fed and potassium in the form of potassium sulfate $\left(48 \% \mathrm{~K}_{2} \mathrm{O}\right)$ at a rate of $48 \mathrm{~kg} \mathrm{~K} \mathrm{~K}_{2} \mathrm{O} /$ fed were applied at three equal doses; the first was added during soil preparation, the second dose after the first cut and the third dose after the second cut. All agriculture practices were done as normal.

Harvesting:

Lemongrass was harvested after 90 days from transplanting. The plants cut close to the base about $10 \mathrm{~cm}$ above ground level. Plants were harvested twice during each year, the first cut was done at the first week of July and the second one was in the first week of October.

Table (1): Some physical and chemical properties of experimental soil before the two years.

\begin{tabular}{|c|c|c|}
\hline The analysis & $\mathbf{1}^{\text {st }}$ year & $\mathbf{2}^{\text {nd }}$ year \\
\hline Physical & & \\
Coarse sand \% & 5.03 & 4.93 \\
Fine Sand \% & 73.60 & 71.90 \\
Silt \% & 12.20 & 13.72 \\
Clay \% & 9.17 & 9.17 \\
Soil texture & Sandy & Sandy \\
Chemical & & \\
pH & 7.93 & 7.98 \\
Organic matter \% & 0.61 & 0.80 \\
T. CaCo & 3.92 & 3.75 \\
Avalable nutrunties & & \\
N (ppm) & 38.2 & 41.9 \\
P (ppm) & 3.7 & 4.10 \\
K (ppm) & 245 & 275 \\
Fe (ppm) & 2.7 & 3.9 \\
Mn (ppm) & 1.3 & 1.7 \\
Zn (ppm) & 0.8 & 0.9 \\
\hline
\end{tabular}

Experimental design was a split-plot design with three replicates. The main plots were assigned to three irrigation intervals ( 3,6 and 12 days). Subplots were devoted to three fertilization levels with Super Bluegreen and/or Super Cetrin foliar spray (at 75, 100 and $150 \mathrm{ppm}$ ). The compounds used for foliar application were provided by the General Organization for Agriculture Equalization Fund (G.O.A.E.F.), Ministry of Agriculture, Egypt. The examined Super Bluegreen is a source of enriched vital azotic fertilizer including the blue-green algae, while Super Cetrin is a mixture of micronutrients containing $\mathrm{Zn}, \mathrm{Mn}$ and $\mathrm{Fe}$ at $6 \%$ of each element. 
Foliar spray was first applied after 45 days from transplanting, twice every month thereafter, and was stopped 15 days before harvesting.

The treatments were as follows:

Control (Spraying with distilled water).

Spraying with Super Bluegreen (SB) at $75 \mathrm{ppm}$.

Spraying with Super Bluegreen (SB) at $100 \mathrm{ppm}$.

Spraying with Super Bluegreen (SB) at $150 \mathrm{ppm}$

Spraying with Super Cetrin (SC) at $75 \mathrm{ppm}$.

Spraying with Super Cetrin (SC) at $100 \mathrm{ppm}$.

Spraying with Super Cetrin (SC) at $150 \mathrm{ppm}$.

Spraying with SB at $75 \mathrm{ppm}+\mathrm{SC}$ at $75 \mathrm{ppm}$.

Spraying with SB at $100 \mathrm{ppm}+\mathrm{SC}$ at $100 \mathrm{ppm}$.

Spraying with SB at $150 \mathrm{ppm}+\mathrm{SC}$ at $150 \mathrm{ppm}$.

\section{Data recorded:}

Fresh weight of harvest (g/ plant): 15 plants were taken from each plot for the three replicates and weighted for plant fresh weight.

Dry weight (g/ plant): plant was air dried until dry weight remained constant and the dry weight was recorded after two consecutive weights.

Herb yield (ton/ fed): was calculated by multiplying plant dry weight by number of plants per feddan (12.121 plant).

Essential oil determination:

Essential oil (\%): was determined in the wilted samples $(50 \mathrm{~g})$ of three replications were cut into small pieces $(1 \times 1 \mathrm{~cm})$ and subjected to hydrodistillation for 3 hrs using Clevenger apparatus according to the method described by Egyptian Pharmacopoeia (1984). The extracted essential oil was dried using anhydrous sodium sulfate and stored in sealed vials at low temperature $\left(2^{\circ} \mathrm{C}\right)$ before analysis.

Essential oil yield: Oil yield per plant was calculated by multiplying the oil \% by average plant yield and expressed as volume in $\mathrm{ml} /$ plant. In addition, total yield was expressed as volume in L/ fed and was calculated by multiplying the oil yield per plant by number of plants per feddan.

Physical and chemical properties of oil: Samples of the two years and harvesting dates were mixed together and the essential oil was extracted to measure its general physical and chemical properties. These measurements were analyzed at the Laboratory of the Chemistry Dept., Fac. Agric., Mansoura Univ. The specific gravity, the refractive index and the optical rotation of the essential oil were determined according the methods described by Guenther (1949). The acid number, saponification number and ester number of the oil were determined by applying the methods described in Guenther (1972).

Essential oil constituents: The resulted oil from the plants irrigated each 6 and 12 days with the mixture of foliar spraying at $100 \mathrm{ppm}$ in the first cut of the second year. The dehydrated oil was separately subjected to Gas Liquid Chromatography Technique analysis at the Medicinal and Aromatic Plants Section, Agric. Research Centre, Giza, by GLC (Varian VISIA series 6200, FID detector). The components of the oils were identified by comparison of their mass specta with those of a computer lirary or with authentic compounds, (Guenther and Joseph 1978). 


\section{Statistical analysis:}

The statistical analysis was carried out according to Gomez and Gomez (1984), and the differences were done using the Least Significant Difference (LSD) test at $5 \%$.

\section{RESULTS AND DISCUSSION}

\section{Herb growth and yield \\ Effect of irrigation intervals:}

The herb fresh and dry weights per plant in addition to dry yield per feddan in both cuts in both years decreased by increasing water irrigation intervals( Table 2). The highest weight per plant and yield / fed resulted from irrigation at 3 days intervals, while the treatment of 12 days irrigation intervals significantly decreased herb weight per plant and yield/ feddan compared with those of 3 and 6 days intervals.

The fresh weight of herb/ plant obtained from the plants irrigated every 3 days averaged ( 358.7 and $438.7 \mathrm{~g} / \mathrm{plant}$ ) in the first and second cuts, respectively in the first year and averaged (764.4 and $526.2 \mathrm{~g} /$ plant ) in the same order in the second one (Table 2). The dry weight of herb / plant obtained from plants irrigated every 3 days averaged (108.9 and $142.4 \mathrm{~g} /$ plant ) in the first and second cuts respectively in the first year and averaged (239.0 and $158.2 \mathrm{~g} /$ plant ) in the same order in the second year (Table 3). The dry weight yield / feddan obtained from the plants irrigated every 3 days averaged (1.277 and 1.725 ton / fed ) in the first and second cuts respectively in the first year and averaged (2.990 and 1.917 ton / fed ) in the same order in the second year (Table 2). This effect may be due to that plants may grow better under frequent irrigation. Water in the root zone facilitates absorption of nutrients essential for growth of pants. Thus, it is very likely that drought conditions and the lack of water negatively affect plant growth and development. Water deficiency has a profound negative effect on plant metabolism including cell wall and cell expansion. Similar results were stated on sunflower plant by Nour El-Din et al. (1994)and Ashoub et al. (2000), on Majorana hortensis plant

by Kandeel and Sharaf (2003), Detpiratmongkol et al. (2005) on lemongrass and El-Mekawy (2006) on Achillea fragrantissima L. plant.

\section{Effect of foliar fertilization:}

Spraying with Super Bluegreen (SB) or Super Cetrin (SC) increased herb fresh and dry weights per plant as well as dry yield per feddan in both cuts in both years compared with the control (Table 2). These increases were higher with increasing concentration of the spray.

However, spraying with Super Cetrin (SC) was more effective in all previously mentioned measurements compared to Super Bluegreen (SB). Meanwhile, higher herb fresh and dry weights per plant in addition to dry yield per feddan in both cuts, in both years (Table 2) resulted from spraying with the mixture of Super Bluegreen + Super Cetrin ( SB 100 + SC 100 ppm). 
Abdel-kader, H.H. et al.

2 
The fresh weight of herb/plant obtained from this treatment averaged (378.0 and $472.3 \mathrm{~g}$ / plant) in the two cuts respectively in the first year and averaged (737.7 and $525.3 \mathrm{~g} /$ plant) in the second year (Table 2).

The dry weight of herb/ plant obtained averaged (127.4 and $145.7 \mathrm{~g} /$ plant ) in the first and second cuts respectively in the first year and averaged (208.8 and $169.7 \mathrm{~g} /$ plant ) in the same order in the second year (Table2).

The dry weight yield /feddan obtained averaged (1.543 and 1.764 ton / fed) in the first and second cuts respectively in the first year and averaged (2.935 and 2.056 ton / fed) in the same order in the second year (Table 2).

The stimulatory of the foliar fertilization treatments on dry weight of herb may be due to the role of bio-fertilization and microelements which was previously mentioned in the case of fresh weight of herb as the increase in this parameter which reflected on dry weight of herb.

Also, solubilization of mineral nutrients, synthesis of vitamins, amino acids and microelements as a result of foliar spray fertilization would stimulate growth and yield (Sprenat, 1990). In this concern, Shoala, (1992) and Refaat, (1996) also reported that foliar application of micronutrients significantly increased lemongrass plant weight.

These results are similar with those found by Eisa (2000) on fennel; Kassem (2002) on rosemary; Reffat and Balbaa (2001) on lemongass; Hashem (2007) on thyme; Abd El-Wahab (2008) on Trachyspermum ammi plant; Leithy et al. (2009) on geranium and Al-Fraihat et al. (2011) on Majorana hortensis plant.

\section{Effect of the interaction between irrigation intervals and foliar fertilization}

Results of Table (3) show that although increasing irrigation intervals up to 12 days decreased herb fresh weight per plant, foliar spray with bio fertilizers reduced the negative effect of this treatment on fresh weight.

The results also revealed that the interaction treatment between (SB $100 \mathrm{ppm}+$ SC 100 ppm) and 3 days intervals recorded the highest herb fresh weight per plant compared to the other interactions. In this concern, similar results were obtained regarding bio-fertilizers by El-Mekawy et al. (2009) on Achillea fragrantissima plant.

In addition, foliar fertilization with micronutrients mixture $(\mathrm{Zn}, \mathrm{Mn}$, and $\mathrm{Fe}$ ) was reported by Reffat and Balbaa (2001) to improve lemon grass growth under water stress conditions.

The fresh weight of herb / plant obtained from this treatment averaged (478 and $602 \mathrm{~g} /$ plant) in the first and second cuts respectively in the first year and averaged (918 and $628 \mathrm{~g} /$ plant) in the same order in the second year (Table 3).

The dry weight of herb / plant obtained averaged (152.4 and $195.3 \mathrm{~g} /$ plant ) in the first and second cuts respectively in the first year and averaged (286.6 and $197.7 \mathrm{~g} /$ plant) in the same order in the second year (Table 3).

The dry weight yield / feddan obtained averaged (1.847 and 2.366 ton / fed ) in the first and second cuts respectively in the first year and averaged (3.710 and 2.396 ton / fed) in the same order in the second year (Table 3). 
Table (3): Effect of the interaction between irrigation intervals and foliar fertilization on the herb fresh and dry weights ( $g$ / plant) and herb yield (ton / fed) of lemongrass in the two cuts during the both years of (2011 and 2012).

\begin{tabular}{|c|c|c|c|c|c|c|c|c|c|c|c|c|c|}
\hline & \multirow{3}{*}{ Treatments } & \multicolumn{4}{|c|}{$\begin{array}{c}\text { Herb fresh } \\
\text { weight } \\
\text { (g/ plant) }\end{array}$} & \multicolumn{4}{|c|}{$\begin{array}{l}\text { Herb dry weight } \\
\text { (g / plant) }\end{array}$} & \multicolumn{4}{|c|}{$\begin{array}{l}\text { Herb yield } \\
\text { (ton / fed) }\end{array}$} \\
\hline & & \multicolumn{2}{|c|}{$1^{\text {st }}$ year } & \multicolumn{2}{|c|}{$2^{\text {nd }}$ year } & \multicolumn{2}{|c|}{$1^{\text {st }}$ year } & \multicolumn{2}{|c|}{$2^{\text {nd }}$ year } & \multicolumn{2}{|c|}{$1^{\mathrm{st}}$ year } & \multicolumn{2}{|c|}{$2^{\text {nd }}$ year } \\
\hline & & $\begin{array}{l}1^{\text {st }} \\
\text { cut }\end{array}$ & $\begin{array}{l}2^{\text {nd }} \\
\text { cut } \\
\end{array}$ & $\begin{array}{c}1^{\text {st }} \\
\text { cut } \\
\end{array}$ & $\begin{array}{l}2^{\text {nd }} \\
\text { cut }\end{array}$ & $\begin{array}{l}1^{\text {st }} \\
\text { cut }\end{array}$ & $\begin{array}{l}2^{\text {nd }} \\
\text { cut }\end{array}$ & $\begin{array}{l}1^{\text {st }} \\
\text { cut }\end{array}$ & $\begin{array}{l}2^{\text {nd }} \\
\text { cut }\end{array}$ & $\begin{array}{l}1^{\text {st }} \\
\text { cut }\end{array}$ & $\begin{array}{l}2^{\text {nd }} \\
\text { cut }\end{array}$ & $\begin{array}{l}1^{\text {st }} \\
\text { cut }\end{array}$ & $\begin{array}{l}2^{\text {nd }} \\
\text { cut }\end{array}$ \\
\hline \multirow{10}{*}{$\begin{array}{c}3 \\
\text { days }\end{array}$} & Control & 190 & 285 & 528 & 323 & 63.4 & 90.2 & 169.1 & 95.7 & 0.771 & 1.085 & 2.049 & 1.156 \\
\hline & Super Bluegreen 75 ppm & 289 & 324 & 722 & 476 & 92.0 & 105.0 & 173.4 & 134.0 & 0.956 & 1.267 & 2.100 & 1.617 \\
\hline & Super Bluegreen $100 \mathrm{ppm}$ & 339 & 411 & 805 & 500 & 105.7 & 131.6 & 255.3 & 152.9 & 1.121 & 1.586 & 3.087 & 1.846 \\
\hline & Super Bluegreen $150 \mathrm{ppm}$ & 301 & 351 & 775 & 480 & 92.8 & 115.1 & 231.0 & 142.2 & 1.111 & 1.385 & 2.800 & 1.715 \\
\hline & Super Cetrin 75 ppm & 350 & 441 & 507 & 502 & 109.0 & 143.5 & 257.9 & 160.8 & 1.278 & 1.735 & 3.129 & 1.945 \\
\hline & Super Cetrin 100 ppm & 395 & 457 & 816 & 583 & 113.8 & 152.9 & 270.0 & 166.4 & 1.376 & 1.845 & 3.200 & 2.017 \\
\hline & Super Cetrin 150 ppm & 369 & 449 & 810 & 575 & 113.5 & 144.2 & 259.8 & 165.5 & 1.317 & 1.746 & 3.146 & 2.014 \\
\hline & SB 75 ppm + SC 75 ppm & 419 & 506 & 858 & 593 & 116.0 & 161.1 & 282.8 & 175.4 & 1.408 & 1.945 & 3.239 & 2.131 \\
\hline & $\begin{array}{c}\text { SB } 100 \text { ppm + SC } 100 \\
\text { ppm }\end{array}$ & 478 & 602 & 918 & 628 & 152.4 & 195.3 & 286.6 & 197.7 & 1.847 & 2.366 & 3.710 & 2.396 \\
\hline & $\begin{array}{c}\text { SB } 150 \text { ppm + SC } 150 \\
\text { ppm }\end{array}$ & 457 & 561 & 903 & 602 & 103.2 & 185.1 & 221.5 & 191.7 & 1.578 & 2.235 & 3.431 & 2.320 \\
\hline \multirow{10}{*}{$\begin{array}{c}6 \\
\text { days }\end{array}$} & Control & 113 & 164 & 310 & 190 & 43.3 & 56.0 & 99.9 & 63.3 & 0.527 & 0.676 & 1.213 & 0.765 \\
\hline & Super Bluegreen 75 ppm & 179 & 268 & 442 & 349 & 82.9 & 59.2 & 146.1 & 102.5 & 1.014 & 0.716 & 1.766 & 1.237 \\
\hline & Super Bluegreen 100 ppm & 240 & 308 & 526 & 486 & 98.4 & 79.4 & 164.3 & 143.1 & 1.187 & 0.956 & 1.987 & 1.728 \\
\hline & Super Bluegreen & 219 & 301 & 461 & 454 & 95.3 & 72.2 & 148.5 & 135.6 & 1.156 & 0.876 & 1.801 & 1.640 \\
\hline & etrin $75 \mathrm{ppm}$ & 252 & 330 & 583 & 489 & 102.7 & 84.1 & 184.4 & 143.2 & 1.256 & 1.016 & 2.235 & 1.756 \\
\hline & Super Cetrir & 282 & 380 & 637 & 540 & 113.3 & 93.5 & 204.3 & 167.1 & 1.367 & 1.134 & 2.477 & 2.023 \\
\hline & Super Cetr & 267 & 360 & 586 & 494 & 103.8 & 87.4 & 184.8 & 163.3 & 1.246 & 1.056 & 2.241 & 1.976 \\
\hline & SB $75 \mathrm{ppm}+\mathrm{SC} 75 \mathrm{ppm}$ & 314 & 396 & 642 & 566 & 118.9 & 102.0 & 206.1 & 168.2 & 1.436 & 1.238 & 2.502 & 2.043 \\
\hline & SB $100 \mathrm{ppm}+\mathrm{SC} 100 \mathrm{ppm}$ & 341 & 430 & 886 & 585 & 133.6 & 113.3 & 284.5 & 192.2 & 1.621 & 1.367 & 3.467 & 2.330 \\
\hline & \begin{tabular}{|c|}
$\begin{array}{c}\text { SB } 150 \text { ppm + SC } 150 \\
\text { ppm }\end{array}$ \\
\end{tabular} & 325 & 400 & 674 & 577 & 126.6 & 105.3 & 206.1 & 180.0 & 1.528 & 1.289 & 2.676 & 2.179 \\
\hline \multirow{10}{*}{$\begin{array}{c}12 \\
\text { days }\end{array}$} & Control & 74 & 163 & 163 & 143 & 24.9 & 45.1 & 54.3 & 49.1 & 0.301 & 0.550 & 0.658 & 0.601 \\
\hline & Super Bluegreen 75 ppm & 152 & 168 & 202 & 153 & 43.8 & 56.1 & 66.9 & 52.3 & 0.534 & 0.675 & 0.814 & 0.634 \\
\hline & Super Bluegreen 100 ppm & 191 & 217 & 232 & 215 & 63.7 & 72.9 & 74.7 & 71.9 & 0.767 & 0.876 & 0.910 & 0.866 \\
\hline & Super Bluegreen 150 ppm & 169 & 207 & 212 & 190 & 56.6 & 68.9 & 72.4 & 62.9 & 0.685 & 0.836 & 0.875 & 0.756 \\
\hline & Super Cetrin 75 ppm & 201 & 237 & 266 & 221 & 66.9 & 78.2 & 85.5 & 74.1 & 0.806 & 0.946 & 1.042 & 0.903 \\
\hline & Super Cetrin 100 ppm & 252 & 290 & 296 & 227 & 79.9 & 94.8 & 97.8 & 80.4 & 0.962 & 1.147 & 1.169 & 0.965 \\
\hline & Super Cetrin 150 ppm & 236 & 263 & 293 & 225 & 78.7 & 85.8 & 96.5 & 75.3 & 0.951 & 1.037 & 1.176 & 0.912 \\
\hline & SB 75 ppm + SC 75 ppm & 273 & 326 & 336 & 240 & 88.1 & 98.6 & 113.0 & 82.6 & 1.067 & 1.205 & 1.372 & 1.002 \\
\hline & SB $100 \mathrm{ppm}+\mathrm{SC} 100 \mathrm{ppm}$ & 315 & 385 & 409 & 363 & 96.1 & 128.4 & 133.8 & 119.2 & 1.156 & 1.564 & 1.624 & 1.435 \\
\hline & $\begin{array}{c}\text { SB } 150 \text { ppm + SC } 150 \\
\text { ppm }\end{array}$ & 279 & 349 & 354 & 331 & 91.9 & 105.9 & 114.9 & 106.5 & 1.134 & 1.276 & 1.386 & 1.286 \\
\hline & L.S.D. $5 \%$ & 246 & 212 & 228 & 433 & 74.2 & 63.3 & 67.7 & 145 & 3.00 & 5.25 & 2.75 & 2.57 \\
\hline
\end{tabular}

Similar results were obtained by Maheshwari et al. (1998) on palmarosa plant and El-Mekawy et al. (2009) on Achillea fragrantissima plant. This might be due to that the used foliar application enhanced the metabolic processes leading to more vegetative growth.

It worth noting that the grass weight produced from the first cut $\left(1^{\text {st }}\right.$ of July) was higher than that produced from the second cut ( $1^{\text {st }}$ of October) because the environmental conditions were more suitable for the growth of lemongrass during the period prior the first of July, since Kybal and Kaplicka (1995) reported that lemongrass prefers an average temperature of $23-$ $30^{\circ} \mathrm{C}$. Accordingly, the temperature conditions during July, August, and September (after the $1^{\text {st }}$ cut until the $2^{\text {nd }}$ cut) were higher than those suitable for lemon grass. 
In addition, the grass yield in the second year was higher than that of the first year, which is logic since plants became older and had more vigorous root systems. These results are in line with those reported by $\mathrm{Pal}$ et al. (1994) who recorded that lemongrass yield is the lowest in the first year and highest in the third or fourth year of planting.

\section{Essential oil production}

Effect of irrigation intervals on essential oil production:

Data in Table (4) showed that the essential oil percentage in either the first or second cut in both years tended to increase with increasing irrigation intervals. The results may be explained by the findings of Penka (1978) who mentioned that essential oils are the product of the respiratory catabolic processes, which increase under the dry conditions of the growing site. In this concern, Aziz et al. (2008) also reported that oil percentage tend to increase due to the drought stress. In addition, the production of essential oil yield per plant and per feddan increased by increasing the irrigation intervals. The highest essential oil yield per plant and per feddan were obtained by the treatment of watering every 12 days (Table 4). Meanwhile, the treatment of irrigation every 3 days resulted in the lowest oil yield per plant and per fed. The increment of the essential oil yield, as a result of the formation and accumulation of essential oil, depended directly upon percentage of oil and / or herb weight.

Similar results were obtained by Afify et al. (1993) on Salvia officinalis plant; Omidbaigia et al. (2003) on Ocimum basilicum plant and Younis et al. (2004) on Jasminum grandiflorum plant.

\section{Effect of foliar fertilization on essential oil production:}

Data in Table (4) showed that the essential oil percentage and yield per plant and per fed were considerably influenced by spraying with microelements fertilization for both years. The results indicated that essential oil \%, content, and yield increased gradually by using foliar application of micronutrient treatments Super Bluegreen (SB), Super Cetrin (SC) and the mixture between them (SB+SC) compared to control plant. Data also showed that Super Cetrin had more effect on essential oil production in both years compared with Super Bluegreen or the control. Such effect may be due to the vital role of Super Cetrin which is a mixture of micronutrients containing $\mathrm{Zn}$, $\mathrm{Mn}$ and $\mathrm{Fe}$ at $6 \%$ of each element.

Generally, the maximum oil production was obtained from plants treated by the mixture of Super Cetrin 100 ppm + Super Bluegreen 100 ppm compared with other treatments under study. These results were observed in both cuts of the two years. These results may be due to that macronutrients are necessary for plant growth and oil yield as well as oil composition.

Many workers, among them Gharib (2001), Kandeel (2002), Min et al. (2005) and Stutte (2006), mentioned that the content of essential oils and their composition are affected by different factors, including genetic makeup and cultivation conditions, such climate, habitat, harvesting time, water stress, and the use of fertilizer.

Similar findings was reported by Kandeel et al. (2004) on sweet basil; Hashem (2007) on thyme; Massoud et al. (2007) on Rosmarinus officonalis L. 
plant; El-Mekawy et al. (2009) on Achillea santolina L plant and Al-Fraihat et al. (2011) on marjoram.

\section{Effect of the interaction between watering intervals and foliar fertilization on essential oil production:}

Data in Table (5) showed that increasing the foliar spray fertilizer and using their mixture with high dose, accompanied with longer irrigation intervals increased percentage and yield of essential oil in both cuts of two years. The maximum values resulted from spraying with Super Bluegreen at $100 \mathrm{ppm}+$ Super Cetrin at $100 \mathrm{ppm}$ in the presence of long irrigation interval (12 days). These results held true in both cuts of the two years. The oil percentage and yield in the grass depend upon several factors such as fertilizer of the soil, climatic conditions, age of the grass, them of cutting, the state of the grass distilled (whether fresh or dry) (Penka, 1978). Biofertilization and microelements might play an active role in activating metabolism processes (anabolism) leading to accumulation in metabolites especially carbohydrates which is considered the backbone of oil formation and production under irrigation intervals conditions.

These results are consistent with the results of Kassem (2002) on rosemary, Singh et al. (2003) on lemon grass, and Abd EL-Wahab (2008) on Trachyspermum ammi L. plant.

It is also clear from the same Table that the essential oil production was affected by harvesting date and that the highest values were obtained from July cutting ( $1^{\text {st }}$ cut) while the lowest were obtained from October cutting ( $2^{\text {nd }}$ cut) in both years, and this might be attributed to the fact that Cymbopogen citratus plants needs enough sunshine for the development of oil in the plant.

In this concern, Kress (2007) confirmed that lemongrass plants should receive the maximum sunshine for better oil yield. Kybal and Kaplicka (1995) also reported that lemongrass requires a warm humid climate with plenty of sunshine uniformly distributed over the year. The lemongrass prefers an average temperature of $23-30^{\circ} \mathrm{C}$. The temperature conditions during July, August, and September (after the $1^{\text {st }}$ cut until the $2^{\text {nd }}$ cut) were higher than those suitable for lemon grass.

It is also clear that oil yield was higher in the second year than the first year since plants became older and had more vigorous root systems. Similarly, Bowes and Zheljazkov (2004) indicated that the yield of oil is less during the first year of establishment and increases in the second year and reaches a maximum in the third and fourth years, after which it declines.

Although previous results on the grass yield (Table 3 ) showed that higher grass yield coincided with short watering intervals (3 days), maximum oil yield was associated with long watering intervals (12 days). These contradicting results could be explained on the basis that conditions leading to higher oil percentage (long intervals of 12 days) compensated for the decrease in grass yield and is more important for oil production. In addition, longer watering intervals means saving water and increasing oil production which is the main economical target for the production of lemongrass. 
J. Plant Production, Mansoura Univ., Vol. 5 (9), September, 2014

4

1515 
Abdel-kader, H.H. et al.

5

1516 
Essential oil properties and constituents

Physical and chemical properties of essential oil:

Identification of the physical properties (specific gravity, refractive index and optical rotation); and the chemical properties (acid number and ester number) of the essential oil of lemongrass leaves are shown in Table (6).

Table (6): Physical and chemical properties of lemongrass essential oil (means of two cuts for two years).

\begin{tabular}{|c|c|}
\hline Properties & Constant \\
\hline Specific gravity at $30^{\circ} \mathrm{C}$ & 0.898 \\
Optical rotation at $30^{\circ} \mathrm{C}$ & -5.62 \\
Refractive index at $30^{\circ} \mathrm{C}$ & 1.491 \\
Total aldehydes $(\%)$ & 74.96 \\
Solubility in $70 \%$ alcohol & - \\
\hline
\end{tabular}

Effect of watering intervals, foliar fertilization and their interaction on essential oil components of lemongrass:

The results of G.L.C. analyses are shown in Table (7) reveale a total of 6 components; 4 oxygenated (linalool, nerol, geranial and geranial acetate) and 2 hydrocarbon compounds (myrcene and limonene).

The identified compounds constituted 83.60 to $98.65 \%$ of the essential oil. The main compound (citral) accounted for 63.84 to $88.63 \%$ of the oil. In this concern, Rabbani et al. (2006) reported that citral is a major component of lemongrass oil, and Formacek and Kubeczka (1982) demonstrated that $C$. citrates produced up to 75 to $85 \%$ citral in their essential oil. Also, Chinese et al. (2005) mentioned that the main component was citral b $(53.98 \%)$, the second was citral a (34.40\%), and the others were under $4 \%$.

Table (7): G.L.C. analyses of the lemongrass essential oil from the $1^{\text {st }}$ cut in the $2^{\text {nd }}$ year from plants subjected to watering intervals ( 3 and 12 days) with foliar fertilization of Super Bluegreen and Super Cetrin alone or in mixture at the rate of $100 \mathrm{ppm}$ each and the control.

\begin{tabular}{|c|c|c|c|c|c|c|c|c|}
\hline \multirow{2}{*}{$\begin{array}{c}\text { Essential oil } \\
\text { Components } \\
(\%)\end{array}$} & \multicolumn{7}{|c|}{ Irrigation intervals (days) } \\
\cline { 2 - 9 } & \multicolumn{7}{|c|}{$\mathbf{3}$} \\
\cline { 2 - 9 } & control & SB & SC & SB+SC & control & SB & SC & SB+SC \\
\hline Myrcene & 2.25 & 4.21 & 6.53 & 5.42 & 2.85 & 3.55 & 5.45 & 8.17 \\
\hline Limonene & 8.83 & 1.14 & 1.00 & 1.54 & 3.09 & 1.92 & 1.20 & 0.78 \\
\hline Linalool & 7.92 & 4.76 & 2.85 & 2.32 & 9.75 & 2.75 & 1.65 & 0.76 \\
\hline Neral (citral a) & 19.79 & 28.50 & 33.47 & 34.90 & 20.23 & 35.35 & 32.07 & 35.60 \\
\hline Geranial (citral b) & 44.05 & 52.00 & 52.61 & 52.37 & 45.18 & 51.60 & 54.96 & 53.03 \\
\hline Geranyl acetate & 2.55 & 2.13 & 1.18 & 1.26 & 2.50 & 1.70 & 1.44 & 0.31 \\
\hline Known & 85.39 & 92.74 & 97.64 & 97.81 & 83.60 & 96.87 & 96.50 & 98.65 \\
\hline
\end{tabular}


The results show that watering intervals every 12 days in addition to foliar application of Super Bluegreen (SB) and Super Cetrin (SC) mixture at the rate of $100 \mathrm{ppm}$ each produced the highest citral a $(35.60 \%)$ and cital b $(53.03 \%)$ compared to the control and other treatments. Citral was slightly affected by drought, and plants from such a dry sandy soil produced relatively more oil yield with high citral content. These results are in agreement with those of Shoala (1992) who reported that the essential oil and citral content increased by spraying lemongrass with $\mathrm{Mn}$ at $50 \mathrm{ppm}$, while Reffat and Balbaa (2001) reported that foliar application of micronutrients mixture (Zn, $\mathrm{Mn}$ and $\mathrm{Fe}$ ) on lemon grass significantly increased essential oil yield and myrcene content.

It could be concluded that lemongrass plants from such a sandy soil produced relatively more oil yield with higher citral content. Also increasing the irrigation interval from 3 to 12 days with different foliar sparing treatments of Super Bluegreen, Super Cetrin and their interaction at $100 \mathrm{ppm}$ of each caused an increase in the essential oil \%, yield and its components.

\section{REFERENCES}

Akhila, A.A. (2010). Essential-bearing grasses: the genus Cymbopogon CRC Press, Taylorand Francis Group. P.108.

Abd EL-Wahab, M.A. (2008). Effect of some trace elements on growth, yield and chemical constituents of Trachysprmum ammi L. plants under Sinai conditions. Research J. Agric.and Biology Sci. 4(6): 717-724.

Afify, S.K.; M.M. Mazrou and M.A. Eraki (1993). The growth and essential oil content of Salvia officinalis L. plants as affected by watering intervals, nitrogen fertilization and their combinations. Zagazig, J. Agric. Res., 20(6): 1913-1924.

AL-Fraihat, A.H.; S.Y. Al-Dalsin; Z.B. Al-Rawashdeh; M.S. Abu-Darwish and J.A. Al-Tabbal (2011). Effect of organic and biofertilizers on growth, herb yield and volatile oil of marjoram plant grown in Ajloun region, $\mathrm{J}$. Med. Plant. Res., 5(13): 2822-2833.

Ashoub, M.A.; I.M.A. Abd El-Aziz; M.M. Shahin and M.N. Gohar (2000). Influence of irrigation intervals and Magnesium fertilization on yield and water relations of sunflower. Annals Agric. Sci. Ain Shams Univ., Cairo. Egypt. 45(2): 453-476.

Aziz, E.E.; S.F. Hendawi; A. Ezz El Din and E.A. Omer (2008). Effect of soil type and irrigation intervals on plant growth, essential oil yield and constituents of Thymus vulgaris plant American- Eurasian J.Agric.\& Environ. Sc., 4(4):443-450.

Bowes, K. and V. Zheljazkov (2004). Essential oil yield and quality of fennel grown in Nova Scotia. Hort. Sci., 39(7):1640-1643.

Chinese, H.; J. Huang; X. Zhang; Y. Chen; J. Yang and L. Hei (2005). Allelopathic effects of (Cymbopogon citratus) volatile and its chemical components. Ying Yong Sheng Tai Xue Bao; 16 (4):763-767. 
Detpiratmongkol, S.; T. Ubolkerd and S. Yousukyingsatapron (2005). Effects of irrigation frequencies and amounts on growth and yield of local lemon grass cultivar. Book Chapter; Conference Paper: Proceedings of $43 \mathrm{rd}$ Kasetsart University Annual Conference, Thailand, 1-4 February, Subject Plants, PP: 632-6

Egyptian Pharmacopoeia (1984). Egyptian Pharmacopoeia, General Organization for Governmental. Printing Office, Ministry of Health, Cairo, Egypt, 31-33.

Egyptian Pharmacopoeia (1984). Egyptian Pharmacopoeia, General Organization for Governmental. Printing Office, Ministry of Health, Cairo, Egypt, 31-33.

Eisa, E.A.E. (2000): Effect of some fertilization treatments on the growth and volatile oil yield on fennel plant. M. Sci. Thesis., Agric. Sci. Inst. Efficient Productivity, Zagazig Univ.

EL- Mekawy, M.A.M. (2006): Effect of irrigation intervals and biofertilization on growth and oil yield of Achillea fragrantissima L. under El-Arish condition. M. Sc. Thesis, Fac. Environ. Agric. Sci. El-Arish, Sues Canal Univ., Egypt.

EL-Mekawy, M.A.; M.D. EL-Deep; A.E. El-Zahwy and H.M. Huwishel (2009): Effect of irrigation intervals and salinity of irrigation water on growth, and chemical composition of Achillea santolina L. plants. J. Agric. Res. Tanta Univ. 32(1): 149-172.

Fereres, E. and M. Soriano (2006). Deficit irrigation for reducing agricultural water use. J. of Experimental Botany. 2(58):147-159.

Formacek, V. and K. Kubeczka (1982). Essential oil analysis by capillary chromatography and carbon-13 NMR spectroscopy. New York: J. Wiley. p. 155-160.

Gharib, F.A. (2001). Morphological and biochemical responses of Tagetes minuta L. plants to foliar application of nicotinamide and micronutrient. Egypt. J. Botany. 41(2): 227-34.

Gomez, K.A. and A.A. Gomez (1984). Statistical Procedures, Res. $2^{\text {nd }}$ Ed. John Wiley and Sons, Inc, New York, USA.

Guenther, E. (1949). The Essential Oils. Vol. (1). History- origin in plants and production analysis. Dr. Van. Nostrand Company., Inc., USA.

Guenther, E. (1972). The Essential Oils, Vol. (1) pub. Robert E. Krieger, Huntingon, New York, USA.

Guenther, Z. and Joseph, S. (1978). Handbook Series in Chromatography. CRC Press, Inc.

Hashem, H.A. (2007). Effect of some fertilization treatments on Thymus vulgaris plant cultivated under north Sinai conditions. M. Sc. Thesis, Fac. Of Agric., Zagazig Univ.

Jain, H.C.; S. Mehta; S. Mehtani; G. Singh; T. Mukherjee; R. Doreswamy and D. Sharma (1994). Report of the workshop on Information Management for the medicinal and aromatic plants industry. J. Sci. Ind. Res., 53(1): 43-46.

Joy, P.; J. Thomas; S. Mathew and J. Joseph( 2001). Aromatic plants. Tropical Horticulture, p. 633-733. 
Kandeel, A.M. (2002). Effect of foliar application with some micronutrients on the vegetative growth, volatile oil yield and chemical composition of Ocimum basilicum L. plant. Annals. Agric. Sci. 47(1): 373-387.

Kandeel, A.M. and M.S. Sharaf. (2003).Produtivity of Majorana hortensis, L. plant as influenced by the interaction between mineral and biological fertilization.J.Agric. Sci. Mansoura Univ. 28 (2):1373-1389.

Kandeel, Y.M.R. (2004). Effect of bio, organic and chemical fertilization on growth, essential oil productivity and chemical composition of Ocimum basilicum L. plant. Annals of Agric. Sci., Moshtohor, 42 (3): 12531270.

Kassem, A.H. (2002). Effect of planting distances and some trace elements on rosemary plant. Ph. D. Thesis. Fac. Agric. Cairo Univ.

Kress, H. (2007). Henriette's Herbal Home Page. Inc. available at www. henriettesherbal.com.

Kybal, J. and J. Kaplicka (1995). Herbs and Spices. Magna Books, Wingston, Prague. Pp. 202-203.

Leithy, S.; M.S. Gaballah and A.M. Gomaa (2009). Associative Impact of Bioand Organic Fertilizers on Geranium plants Grown Under Saline conditions. International . J. of Academic Res.1(1):17-23.

Maheshwari, S.K; R.K. Sharma and S.K. Gangrade (1998). Response of palmarosa (Cymbopogon martini var, motia) to biofertilization, nitrogen and Phosphorus in a shallow black soil under rain fed condition. Indian J. Agron 43(1):175-178.

Massoud, H.Y.A.; M.K. Abd El-shafy and M. El-Eraky (2007). Influence of planting dates and distances on growth and essential oil productivity of Rosmarinus officonalis L. plant. J. Agric. Sci., Mansoura Univ., 32(4): 2719-2737.

Matasyoh, J.C.; I.N. Wagara; J.L. Nakavuma and A.M. Kibural (2011). Chemical composition of Cymbopogon citratus essential oil and its effect on mycotoxigenic Aspergillus species. Afr. J. Food Sci., 5(3): 138-142.

Mohamed, H.A.; Y. Sallam; A. El-Leithy and S.E. Aly (2012). lemongrass (Cymbopogon citratus) essential oil as affected by drying methods. Annals of Agric. Scie., 57(2): 113-116.

Min, S.Y.; A. Tawaha and K. Lee (2005). Effect of ammonium concentration on the yield, mineral content and active terpene components of Chrysanthemum coronarium L. in a hydroponic System. Res. J. Agric. Biol. Sci., 1(2): 170-175.

Nour El-Din, N.A.; A.A. Abd El- Halim; K.I.T. Ibrahim and O.A.H. Sameha (1994). Performance of Sunflower under some Eco-Agricultural factors. Annals Agric. Sci., Ain Shams Univ., Cairo, Egypt. 39(2):633647.

Omidbaigia, R.; A. Hassani and F. Sefidkon (2003). Essential oil content and composition of sweet basil (Ocimum basilicum L.) at different irrigation regimes .J. Essential Oil Bearing Plants. 6(2):104-108.

Pal, S.; S. Balyan; P. Dutt and B. Rao (1994). Effect of time of planting on growth and oil yield in lemongrass. Indian Perfumer, 38(2): 65-67. 
Penka, M. (1978). Influence of irrigation on the contents of effective substances in official plants. Acta Horticulturae, 73:181-189.

Rabbani,SI.; K. Devi; S. Khanam and N. Zahra (2006). Citral, a component of lemongrass oil inhibits the clastogenic effect of nickel chloride in mouse micronucleus test system. Pak J. Pharm. Sci., 19 (2):108-113.

Refaat, A.M. (1996). Effectof soil and foliar nutrition on growth and volatile Oil of lemongrass plant. Bull. Fac. Agric., Cairo Univ., (47): 629-638.

Reffaat, A.M. and L.K. Balbaa (2001). Yield and quality of lemongrass plants (Cymbopogon flexusus Stapf) in relation to foliar application of some vitamins and microelements . Egyptian J. Hort. 28(1): 41-57.

Shoala, A. T. (1992). Effect of irrigation and chemical fertilization treatments on lemon grass (Cymbopogon citratis L.) plants. M.Sc. Thesis, Fac. Agric., Cairo Univ.

Singh, R.K.; R.P. Singh and R.S. Singh (2003). Effect of iron on herbage and oil yield of lemongrass (Cymbopogon flexuosus). Crop Res. 26 (1): 185-187.

Sprenat, M. (1990). Nitrogen-Fixing Organisms. P.S. Chapman and Hall, London.

Stutte, G.W. (2006). Process and product: recirculation hydroponics and bioactive compound in a controlled environment. Hort. Sci., 41: 526530.

Weiss, E.A. (1997). Essential Oil Crops. CAB International, Wallingford, UK., PP. 86-103.

Younis, S.I.; N. Ghaly and S. Kotb (2004). Effect of FYM and planting space on the vegetative growth, active ingredient and chemical composition of Ammi visnage, L. J. Agric. Sci. Mansoura Univ., 29(4): 1985-1993. 
تأثثر فترات الرى والتسميد الورقى على نبات حشيشة الليمون

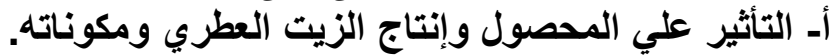

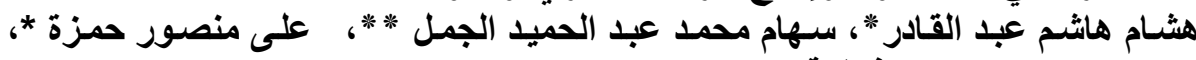

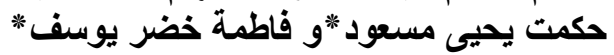

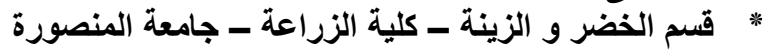

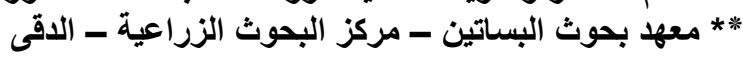

أجريت تجربة حقلية ممتدة لعامين في تربة رملية بمزر الرعة خاصة فى مدينة دمياط الجديدة - محافظة

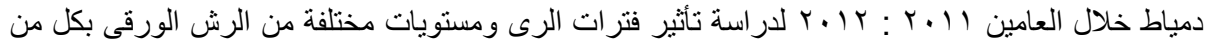

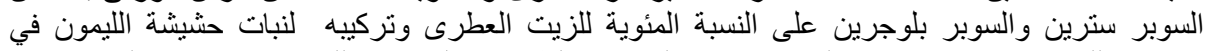

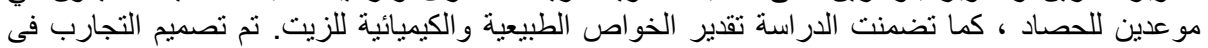

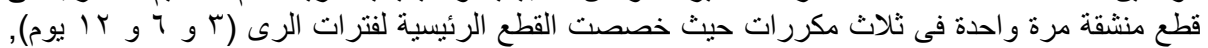

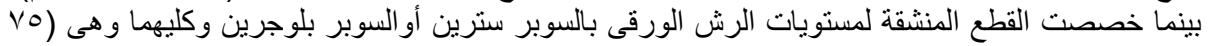

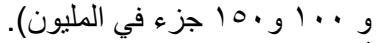

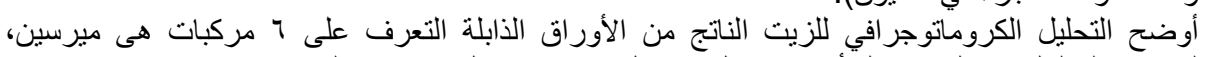

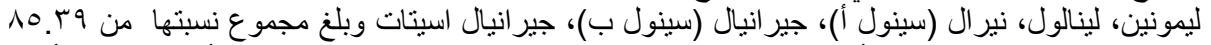

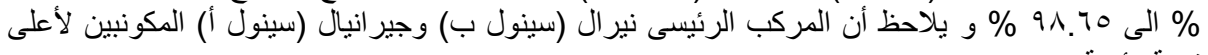
نسبة مئوية. وكانت النتائج المتحصل عليها كالآنى:ـ ـ أدى الرى كل ؟ يوم الى زيادة معنوية فى محصول العشب الطازج والجاف للنبات وأيضا محصول

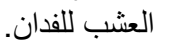

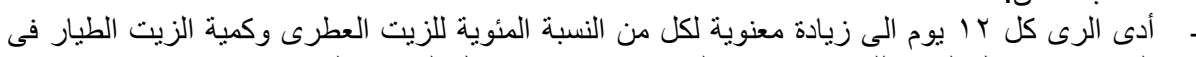

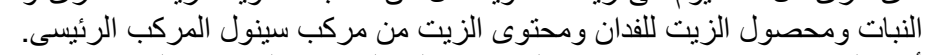

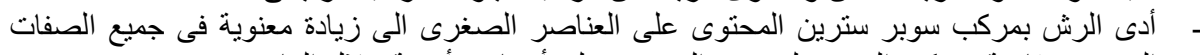

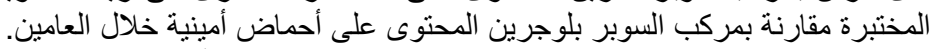

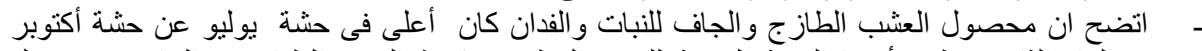

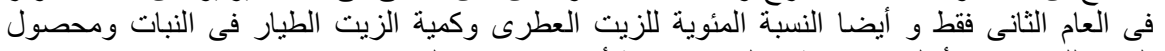

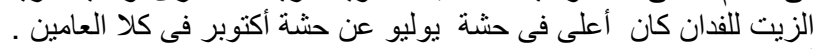

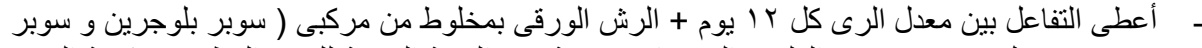

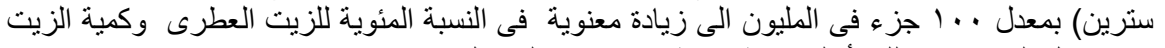

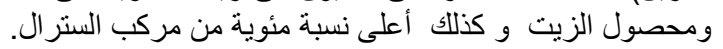

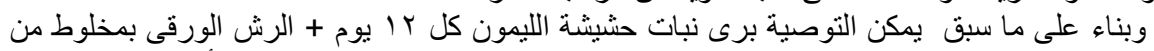

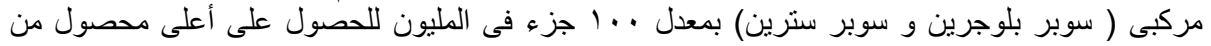
الزيت العطرى ومركب السترال (المركب الرئيسى) تحت ظروف التجرئ. 
Table (2): Effect of irrigation intervals and foliar fertilization on herb fresh and dry weight ( $\mathrm{g} / \mathrm{plant}$ ), herb yield (ton / fed) of lemongrass plant in the two cuts during the two summer years of (2011 and 2012).

\begin{tabular}{|c|c|c|c|c|c|c|c|c|c|c|c|c|}
\hline \multirow{3}{*}{ Treatments } & \multicolumn{4}{|c|}{$\begin{array}{c}\text { Herb fresh weight } \\
\text { (g/ plant) }\end{array}$} & \multicolumn{4}{|c|}{$\begin{array}{l}\text { Herb dry weight } \\
\text { (g/ plant) }\end{array}$} & \multicolumn{4}{|c|}{$\begin{array}{l}\text { Herb yield } \\
\text { (ton / fed) }\end{array}$} \\
\hline & \multicolumn{2}{|c|}{$1^{\text {st }}$ year } & \multicolumn{2}{|c|}{$2^{\text {nd }}$ year } & \multicolumn{2}{|c|}{$1^{\text {st }}$ year } & \multicolumn{2}{|c|}{$2^{\text {nd }}$ year } & \multicolumn{2}{|c|}{$1^{\text {st }}$ year } & \multicolumn{2}{|c|}{$2^{\text {nd }}$ year } \\
\hline & $\begin{array}{l}1^{\text {st }} \\
\text { cut }\end{array}$ & $\begin{array}{l}2^{\text {nd }} \\
\text { cut }\end{array}$ & $\begin{array}{l}1^{\text {st }} \\
\text { cut }\end{array}$ & $\begin{array}{l}2^{\text {nd }} \\
\text { cut }\end{array}$ & $\begin{array}{l}1^{\text {st }} \\
\text { cut }\end{array}$ & $2^{\text {nd }}$ cut & $\begin{array}{l}1^{\text {st }} \\
\text { cut }\end{array}$ & $\begin{array}{l}2^{\text {nd }} \\
\text { cut }\end{array}$ & $\begin{array}{l}1^{\text {st }} \\
\text { cut }\end{array}$ & $\begin{array}{l}2^{\text {nd }} \\
\text { cut }\end{array}$ & $\begin{array}{l}1^{\text {st }} \\
\text { cut }\end{array}$ & $\begin{array}{l}2^{\text {nd }} \\
\text { cut }\end{array}$ \\
\hline \multicolumn{13}{|c|}{ Irrigation intervals } \\
\hline 3 days & 358.7 & 438.7 & 764.4 & 526.2 & 108.9 & 142.4 & 239.0 & 158.2 & 1.277 & 1.725 & 2.990 & 1.917 \\
\hline 6 days & 253.2 & 333.7 & 574.7 & 473.0 & 101.9 & 85.2 & 184.7 & 145.9 & 1.212 & 1.032 & 2.237 & 1.767 \\
\hline 12 days & 214.2 & 260.5 & 276.3 & 230.8 & 69.1 & 83.5 & 91.0 & 77.4 & 0.858 & 1.011 & 1.102 & 0.937 \\
\hline \multirow{2}{*}{\multicolumn{13}{|c|}{ 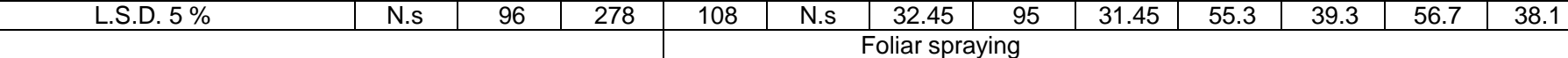 }} \\
\hline & & & & & & & & & & & & \\
\hline Control & 125.7 & 204.0 & 333.7 & 218.7 & 43.9 & 63.8 & 107.8 & 69.4 & 0.532 & 0.772 & 1.306 & 8.41 \\
\hline Super Bluegreen $75 \mathrm{ppm}$ & 206.7 & 253.3 & 455.3 & 326.0 & 72.9 & 73.4 & 128.8 & 96.3 & 0.833 & 0.89 & 1.560 & 1.166 \\
\hline Super Bluegreen 100 ppm & 256.7 & 312.0 & 521.0 & 400.3 & 89.3 & 94.6 & 164.8 & 122.6 & 1.029 & 1.146 & 1.996 & 1.486 \\
\hline Super Bluegreen 150 ppm & 229.7 & 286.3 & 482.7 & 374.7 & 81.6 & 85.4 & 150.6 & 113.6 & 0.985 & 1.034 & 1.825 & 1.376 \\
\hline Super Cetrin 75 ppm & 267.7 & 336.0 & 452.7 & 404.0 & 92.9 & 101.9 & 175.9 & 126.0 & 1.116 & 1.235 & 2.132 & 1.527 \\
\hline Super Cetrin 100 ppm & 309.7 & 375.7 & 583.0 & 450.0 & 102.3 & 113.7 & 190.7 & 138.0 & 1.237 & 1.378 & 2.283 & 1.672 \\
\hline Super Cetrin 150 ppm & 290.7 & 357.3 & 563.0 & 431.3 & 98.7 & 105.8 & 180.4 & 134.7 & 1.173 & 1.282 & 2.191 & 1.631 \\
\hline SB 75 ppm + SC 75 ppm & 335.3 & 409.3 & 612.0 & 466.3 & 107.7 & 120.6 & 200.6 & 142.1 & 1.304 & 1.460 & 2.369 & 1.721 \\
\hline SB $100 \mathrm{ppm}+\mathrm{SC} 100 \mathrm{ppm}$ & 378.0 & 472.3 & 737.7 & 525.3 & 127.4 & 145.7 & 208.8 & 169.7 & 1.543 & 1.764 & 2.935 & 2.056 \\
\hline SB $150 \mathrm{ppm}+$ SC $150 \mathrm{ppm}$ & 353.7 & 436.7 & 643.7 & 503.3 & 116.2 & 132.1 & 207.0 & 159.4 & 1.408 & 1.601 & 2.501 & 1.931 \\
\hline L.S.D. $5 \%$ & 122 & 134 & 232 & 131 & 41.5 & 38.7 & 77 & 36.0 & 0.51 & 0.47 & 0.92 & 0.44 \\
\hline
\end{tabular}



J. Plant Production, Mansoura Univ., Vol. 5 (9): 1505-1522, 2014

Table (4): Effect of irrigation intervals and foliar fertilization on the essential oil production of lemongrass in the two cuts during the both years 2011 and 2012.

\begin{tabular}{|c|c|c|c|c|c|c|c|c|c|c|c|c|}
\hline \multirow{3}{*}{ Treatments } & \multicolumn{4}{|c|}{$\begin{array}{l}\text { Essential oil } \\
\text { (\%) }\end{array}$} & \multicolumn{4}{|c|}{$\begin{array}{l}\text { Essential oil content } \\
\text { (ml / plant) }\end{array}$} & \multicolumn{4}{|c|}{$\begin{array}{l}\text { Essential oil yield } \\
(\mathrm{L} / \mathrm{fed})\end{array}$} \\
\hline & \multicolumn{2}{|c|}{$1^{\text {st }}$ year } & \multicolumn{2}{|c|}{$2^{\text {nd }}$ year } & \multicolumn{2}{|c|}{$1^{\text {st }}$ year } & \multicolumn{2}{|c|}{$2^{\text {nd }}$ year } & \multicolumn{2}{|c|}{$1^{\text {st }}$ year } & \multicolumn{2}{|c|}{$2^{\text {nd }}$ year } \\
\hline & $\begin{array}{l}1^{\text {st }} \\
\text { cut }\end{array}$ & $\begin{array}{l}2^{\text {nd }} \\
\text { cut }\end{array}$ & $\begin{array}{l}1^{\text {st }} \\
\text { cut }\end{array}$ & $\begin{array}{l}2^{\text {nd }} \\
\text { cut }\end{array}$ & $\begin{array}{l}1^{\text {st }} \\
\text { cut }\end{array}$ & $\begin{array}{l}2^{\text {nd }} \\
\text { cut }\end{array}$ & $\begin{array}{l}1^{\text {st }} \\
\text { cut }\end{array}$ & $\begin{array}{l}2^{\text {nd }} \\
\text { cut }\end{array}$ & $\begin{array}{l}1^{\text {st }} \\
\text { cut }\end{array}$ & $\begin{array}{l}2^{\text {nd }} \\
\text { cut }\end{array}$ & $\begin{array}{l}1^{\text {st }} \\
\text { cut }\end{array}$ & $\begin{array}{l}2^{\text {nd }} \\
\text { cut }\end{array}$ \\
\hline & \multicolumn{12}{|c|}{ Irrigation intervals } \\
\hline 3 days & 1.2 & 1.0 & 2.8 & 1.1 & 2.4 & 2.1 & 5.7 & 2.2 & 29.2 & 26.0 & 68.8 & 26.7 \\
\hline 6 days & 1.3 & 1.1 & 2.8 & 1.1 & 4.1 & 3.1 & 12.5 & 2.5 & 46.1 & 36.4 & 146.2 & 29.5 \\
\hline 12 days & 1.4 & 1.2 & 3.3 & 1.2 & 4.3 & 3.8 & 15.9 & 3.7 & 52.0 & 45.5 & 193.0 & 45.0 \\
\hline L.S.D. $5 \%$ & 0.27 & 0.09 & 0.19 & 0.11 & 4.82 & 3.17 & 9.34 & 2.14 & 58.5 & 22.5 & 67.1 & 25.9 \\
\hline \multicolumn{13}{|c|}{ Foliar spraying } \\
\hline Control & 0.9 & 0.7 & 2.5 & 0.9 & 1.6 & 1.0 & 7.6 & 1.6 & 19.4 & 12.3 & 78.3 & 19.6 \\
\hline Super Bluegreen 75 ppm & 1.1 & 0.8 & 2.7 & 0.9 & 2.0 & 1.9 & 8.6 & 1.9 & 24.4 & 22.2 & 103.7 & 22.8 \\
\hline Super Bluegreen 100 ppm & 1.2 & 1.0 & 2.8 & 1.1 & 3.0 & $2 ; 8$ & 9.8 & 2.3 & 36.0 & 33.6 & 118.5 & 28.3 \\
\hline Super Bluegreen 150 ppm & 1.2 & 0.9 & 2.7 & 1.0 & 2.7 & 2.6 & 9.6 & 2.3 & 32.7 & 28.0 & 113.4 & 27.5 \\
\hline Super Cetrin 75 ppm & 1.3 & 1.0 & 2.9 & 1.2 & 3.4 & 2.9 & 10.7 & 2.5 & 37.8 & 35.2 & 129.1 & 30.6 \\
\hline Super Cetrin 100 ppm & 1.4 & 1.2 & 3.1 & 1.2 & 4.3 & 3.3 & 12.7 & 2.9 & 48.4 & 39.5 & 153.7 & 35.7 \\
\hline Super Cetrin 150 ppm & 1.3 & 1.1 & 3.0 & 1.2 & 3.9 & 3.1 & 11.6 & 2.7 & 43.7 & 37.4 & 141.3 & 33.3 \\
\hline SB 75 ppm + SC 75 ppm & 1.5 & 1.3 & 3.1 & 1.2 & 4.5 & 3.7 & 13.0 & 3.2 & 52.7 & 44.9 & 157.5 & 39.3 \\
\hline SB 100 ppm +SC 100 ppm & 1.7 & 1.6 & 3.4 & 1.5 & 5.7 & 4.6 & 16.2 & 4.4 & 69.2 & 56.2 & 196.0 & 53.5 \\
\hline SB $150 \mathrm{ppm}+$ SC 150 ppm & 1.6 & 1.4 & 3.3 & 1.4 & 5.0 & 4.1 & 13.9 & 3.9 & 60.1 & 50.2 & 168.4 & 46.8 \\
\hline L.S.D. $5 \%$ & 0.45 & 0.66 & 0.16 & 0.16 & 0.62 & 1.84 & 5.12 & 1.19 & 35.5 & 22.5 & 62.1 & 14.5 \\
\hline
\end{tabular}



Table (5): Effect of the interaction between irrigation intervals and foliar fertilization on the essential oil Production of lemongrass in the two cuts during the both years of (2011 and 2012).

\begin{tabular}{|c|c|c|c|c|c|c|c|c|c|c|c|c|c|}
\hline & \multirow{4}{*}{ Treatments } & \multicolumn{4}{|c|}{$\begin{array}{c}\begin{array}{c}\text { Essential oil } \\
(\%)\end{array} \\
\end{array}$} & \multicolumn{4}{|c|}{$\begin{array}{l}\text { Essential oil content } \\
\text { (ml / plant) }\end{array}$} & \multicolumn{4}{|c|}{$\begin{array}{c}\text { Essential oil yield } \\
(L / f e d)\end{array}$} \\
\hline & & \multirow{2}{*}{\multicolumn{2}{|c|}{$1^{\text {st }}$ year }} & \multirow{2}{*}{\multicolumn{2}{|c|}{$2^{\text {na }}$ year }} & \multicolumn{2}{|c|}{$1^{\text {st }}$ year } & \multicolumn{2}{|c|}{$2^{\text {na }}$ year } & \multicolumn{2}{|c|}{$1^{\text {st }}$ year } & \multicolumn{2}{|c|}{$2^{\text {na }}$ year } \\
\hline & & & & & & & & & & & & & \\
\hline & & cut & cut & cut & cut & cut & cut & $1^{\text {st }}$ cut & $2^{\text {nd }}$ cut & & $2^{\text {nd }}$ cut & & 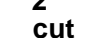 \\
\hline \multirow{10}{*}{$\begin{array}{l}3 \\
\text { days }\end{array}$} & Control & 0.9 & 0.5 & 2.3 & 0.8 & 1.3 & 0.6 & 3.4 & 1.1 & 15.4 & 7.2 & 41.5 & 13.4 \\
\hline & Super Bluegreen 75 ppm & 1.0 & 0.7 & 2.5 & 0.9 & 1.4 & 1.4 & 4.0 & 1.3 & 17.2 & 17.0 & 48.4 & 15.6 \\
\hline & Super Bluegreen $100 \mathrm{ppm}$ & 1.2 & 0.8 & 2.5 & 1.0 & 2.2 & 2.1 & 4.6 & 1.8 & 26.7 & 25.0 & 56.2 & 21.6 \\
\hline & Super Bluegreen $150 \mathrm{ppm}$ & 1.1 & 0.7 & 2.5 & 0.9 & 1.8 & 1.6 & 4.6 & 1.7 & 21.8 & 19.6 & 55.3 & 20.8 \\
\hline & Super Cetrin 75 ppm & 1.2 & 0.9 & 2.6 & 1.1 & 2.5 & 2.2 & 5.5 & 1.9 & 30.5 & 26.9 & 64.4 & 23.0 \\
\hline & Super Cetrin $100 \mathrm{ppm}$ & 1.2 & 1.1 & 2,9 & 1.2 & 2.8 & 2.5 & 5.7 & 2.2 & 33.4 & 30.5 & 68.4 & 30.8 \\
\hline & Super Cetrin 150 ppm & 1.2 & 1.1 & 2,9 & 1.2 & 2.7 & 2.4 & 5.3 & 2.2 & 32.6 & 29.6 & 66.7 & 26.1 \\
\hline & SB $75 \mathrm{ppm}+\mathrm{SC} 75 \mathrm{ppm}$ & 1.4 & 1.2 & 2.9 & 1.2 & 2.9 & 2.6 & 6.2 & 2.6 & 33.6 & 31.9 & 75.0 & 31.6 \\
\hline & SB $100 \mathrm{ppm}+\mathrm{SC} 100 \mathrm{ppm}$ & 1.6 & 1.3 & 3.3 & 1.4 & 3.8 & 3.2 & 9.2 & 4.0 & 46.5 & 38.6 & 111.1 & 48.5 \\
\hline & SB $150 \mathrm{ppm}+\mathrm{SC} 150 \mathrm{ppm}$ & 1.5 & 1.3 & 3.1 & 1.3 & 2.9 & 2.8 & 8.3 & 2.9 & 34.5 & 33.9 & 100.4 & 35.4 \\
\hline \multirow{10}{*}{$\begin{array}{c}6 \\
\text { days }\end{array}$} & Cont & 0.9 & 0.7 & 2.4 & 0.9 & 1.7 & 0.7 & 9.5 & 1.5 & 20.0 & 8.8 & 74.3 & 17.9 \\
\hline & Super Bluegreen 75 ppm & 1.1 & 0.9 & 2.6 & 0.9 & 2.0 & 2.0 & 9.7 & 1.6 & 24.8 & 24.4 & 114.7 & 19.5 \\
\hline & Super Bluegreen $100 \mathrm{ppm}$ & 1.2 & 1.0 & 2.6 & 1.1 & 3.0 & 2.7 & 10.3 & 1.9 & 36.3 & 32.8 & 124.8 & 22.6 \\
\hline & Super Bluegreen $150 \mathrm{ppm}$ & 1.1 & 0.9 & 2.6 & 0.9 & 3.0 & 2.9 & 10.3 & 1.7 & 35.3 & 26.4 & 117.2 & 21.1 \\
\hline & Super Cetri & 1.3 & 1.1 & 2.8 & 1.2 & 3.8 & 3.0 & 11.6 & 2.1 & 36.8 & 36.0 & 140.6 & 25.1 \\
\hline & Super Cett & 1.4 & 1.2 & 2.9 & 1.2 & 4.5 & 3.4 & 13.8 & 2.5 & 54.6 & 41.9 & 166.9 & 26.5 \\
\hline & Super Cetrin 150 ppm & 1.4 & 1.1 & 2.8 & 1.2 & 4.3 & 3.2 & 12.5 & 2.4 & 47.1 & 38.8 & 150.9 & 28.8 \\
\hline & SB $75 \mathrm{ppm}+\mathrm{SC} 75 \mathrm{ppm}$ & 1.7 & 1.4 & 3.1 & 1.3 & 6.1 & 3.7 & 14.2 & 2.9 & 56.2 & 45.3 & 171.6 & 35.4 \\
\hline & SB $100 \mathrm{ppm}+\mathrm{SC} 100 \mathrm{ppm}$ & 1.8 & 1.5 & 3.4 & 1.5 & 6.9 & 4.9 & 18.7 & 4.2 & 77.7 & 59.1 & 226.5 & 50.8 \\
\hline & SB $150 \mathrm{ppm}+\mathrm{s}$ & 1.6 & 1.5 & 3.1 & 1.3 & 6.1 & 4.1 & 14.4 & 3.9 & 72.3 & 50.2 & 174.2 & 47.6 \\
\hline \multirow{11}{*}{$\begin{array}{c}12 \\
\text { days }\end{array}$} & Cor & 1.0 & 0.9 & 2.8 & 0.9 & 1.9 & 1.7 & 9.8 & 2.3 & 22.9 & 21.0 & 119.1 & 27.6 \\
\hline & Super Bluegreen 75 ppm & 1.2 & 1.0 & 3.0 & 0.9 & 2.6 & 2.2 & 12.2 & 2.7 & 31.1 & 25.1 & 147.9 & 33.2 \\
\hline & Super Bluegreen & 1.2 & 1.1 & 3.2 & 1.2 & 3.7 & 3.5 & 14.4 & 3.4 & 45.1 & 43.1 & 174.6 & 40.8 \\
\hline & Super Bluegreen $150 \mathrm{ppm}$ & 1.3 & 1.0 & 3.1 & 1.1 & 3.4 & 3.1 & 13.8 & 3.3 & 41.1 & 38.0 & 167.8 & 40.5 \\
\hline & Super Cetrin $75 \mathrm{ppm}$ & 1.3 & 1.1 & 3.3 & 1.2 & 3.9 & 3.6 & 15.0 & 3.6 & 46.1 & 42.8 & 182.2 & 43.8 \\
\hline & Super Cetrin & 1.4 & 1.4 & 3.3 & 1.2 & 5.6 & 3.8 & 18.6 & 4.1 & 57.2 & 46.1 & 225.7 & 49.8 \\
\hline & Super Cetrin 150 ppm & 1.4 & 1.2 & 3.3 & 1.2 & 4.7 & 3.6 & 17.0 & 3.7 & 51.5 & 43.8 & 206.3 & 45.0 \\
\hline & SB $75 \mathrm{ppm}+\mathrm{SC} 75 \mathrm{ppm}$ & 1.6 & 1.4 & 3.4 & 1.3 & 4.7 & 4.6 & 18.6 & 4.2 & 68.3 & 57.5 & 225.8 & 50.9 \\
\hline & SB $100 \mathrm{ppm}+\mathrm{SC} 100 \mathrm{ppm}$ & 1.8 & 1.5 & 3.6 & 1.7 & 6.4 & 5.9 & 20.7 & 5.0 & 83.4 & 71.0 & 250.4 & 61.1 \\
\hline & SB $150 \mathrm{ppm}+\mathrm{SC} 150 \mathrm{ppm}$ & 1.7 & 1.9 & 3.6 & 1.7 & 6.0 & 5.5 & 19.0 & 4.7 & 73.5 & 66.4 & 230.5 & 57.3 \\
\hline & L.S.D. $5 \%$ & 0.76 & 1.09 & 0.54 & 0.27 & 2.29 & 1.31 & 2.53 & 1.16 & 7.6 & 15.9 & 113.2 & 14.1 \\
\hline
\end{tabular}

